\title{
LCZ696 (sacubitril/valsartan), an angiotensin receptor neprilysin inhibitor (ARNI): clinical development in heart failure
}

\author{
Martin P Lefkowitz \\ From 7th International Conference on cGMP Generators, Effectors and Therapeutic Implications \\ Trier, Germany. 19-21 June 2015
}

Neurohormonal pathways are of critical importance in the pathogenesis and progression of heart failure. Current heart failure therapies mainly focus on blocking the detrimental effects of long-term neurohormonal activation and largely ignore the physiological compensatory effect of the natriuretic peptide system and other endogenous vasodilator systems. Natriuretic peptides exert their effects by activating membrane-bound guanylyl cyclase-coupled receptors (NPR-A and -B), resulting in increased concentrations of the second messenger cyclic guanosine monophosphate (cGMP) [1].

LCZ696 (sacubitril/valsartan) exhibits the novel mechanism of action of an angiotensin receptor neprilysin inhibitor (ARNI) by simultaneously inhibiting neprilysin (neutral endopeptidase; NEP) via LBQ657, the active metabolite of the prodrug sacubitril (AHU377), and blocking the angiotensin II type-1 receptor via valsartan [2]. The cardiovascular effects of LCZ696 in heart failure patients are attributed to the enhancement of peptides that are degraded by neprilysin such as natriuretic peptides by LBQ657 and the simultaneous inhibition of the deleterious effects of angiotensin II by valsartan.

In the PARADIGM-HF study of 8442 patients with heart failure and reduced ejection fraction (HFrEF), LCZ696 reduced the primary endpoint of cardiovascular death or heart failure hospitalization by $20 \%$ and reduced death due to any cause by $16 \%$ (both $\mathrm{p}<0.001$ ) compared with the ACE-inhibitor enalapril. Symptoms and physical functioning, as assessed by the Kansas City Cardiomyopathy Questionnaire (patient assessment) and NYHA classification (physician assessment), were also favourably impacted by LCZ696 vs. enalapril. LCZ696 increased levels

Correspondence: marty.lefkowitz@novartis.com

Cardiovascular Metabolism, Novartis Pharmaceuticals Corporation, East Hanover, NJ 10901, USA 
6. Solomon SD, Zile M, Pieske B, Voors A, Shah A, Kraigher-Krainer E, et al: The angiotensin receptor neprilysin inhibitor LCZ696 in heart failure with preserved ejection fraction: a phase 2 double-blind randomised controlled trial. Lancet 2012, 380(9851):1387-1395.

7. ClinicalTrials.gov identifier NCT01920711.

doi:10.1186/2050-6511-16-S1-A1

Cite this article as: Lefkowitz: LCZ696 (sacubitril/valsartan), an angiotensin receptor neprilysin inhibitor (ARNI): clinical development in heart failure. BMC Pharmacology and Toxicology 2015 16(Suppl 1):A1.

Submit your next manuscript to BioMed Central and take full advantage of:

- Convenient online submission

- Thorough peer review

- No space constraints or color figure charges

- Immediate publication on acceptance

- Inclusion in PubMed, CAS, Scopus and Google Scholar

- Research which is freely available for redistribution

Submit your manuscript at www.biomedcentral.com/submit
C Biomed Central 